\title{
Effect of Nitrogen Source on Pac Choi (Brassica rapa L.) Chemistry and Interactions with the Diamondback Moth (Plutella xylostella L.)
}

\author{
Wendy A. Johnson ${ }^{1}$, Raymond A. Cloyd, and James R. Nechols \\ Department of Entomology, Kansas State University, 123 Waters Hall, \\ Manhattan, KS 66506
}

Kimberly A. Williams

Department of Horticulture, Forestry and Recreation Resources, Kansas

State University, Manhattan, KS 66506-5506

\author{
Nathan O. Nelson \\ Department of Agronomy, Kansas State University, Manhattan, KS 66506
}

Dorith Rotenberg and Megan M. Kennelly

Department of Plant Pathology, Kansas State University, Manhattan, KS 66506

Additional index words. plant-insect interactions, nitrogen, conventional, organic, fertilizer, insect fitness

\begin{abstract}
Two greenhouse studies were conducted to examine effects of nitrogen source on primary and secondary metabolism of pac choi (Brassica rapa L. subsp. chinensis cv. Mei Qing Choi) and diamondback moth (Plutella xylostella L.) consumption, development, survival, and body weight. Applications of a liquid organic source of nitrogen (fish hydrolysate fertilizer) were compared with a conventional fertilizer to determine whether nitrogen source directly impacts pac choi chemistry (elemental composition and phenolics) and biomass and indirectly affects diamondback moth fitness parameters. There was no significant effect of fertility treatment on pac choi chemistry or biomass with the exception of percent leaf phosphorus, which was significantly higher in the conventional fertility treatment, and p-coumarin, which was significantly higher in the organic fertility treatment. Diamondback moth also affected plant chemistry. Both calcium (Ca) and magnesium (Mg) were significantly higher in plants infested with larvae compared with uninfested plants. Fertilizer affected diamondback moth fitness with percent survival and cohort development significantly reduced on pac choi associated with the organic fertilizer. However, pac choi receiving the organic treatment was similar in regard to primary nutrients and secondary compounds compared with plants that received a conventional fertilizer.
\end{abstract}

Nitrogen $(\mathrm{N})$ is an essential nutrient that crops require for growth and development (Jones, 1998; Raven and Smith, 1976). The

\footnotetext{
Received for publication 17 May 2012. Accepted for publication 6 Aug. 2012.

This study was supported by USDA/IOP Program Award No. CS9979. This is Contribution Number 12-363-J of the Kansas State Agricultural Experiment Station.

We thank the following people, all from Kansas State University: Dr. Channa Rajashaker and Dr. Myung-Min Oh, Department of Horticulture, Forestry and Recreation Resources, for consultation and training concerning phytochemical analyses and for providing laboratory space; Kathy Lowe, Soil Testing Lab, and Cheryl Armendariz, Ruminant Nutrition Lab, for help in processing samples; and Dr. Anthony Joern and Dr. Mary Beth Kirkham for reviewing a previous draft of the manuscript.

${ }^{1}$ To whom reprint requests should be addressed; e-mailwendyann@ksu.edu.
}

1981). A decrease in soil $\mathrm{N}$ may limit protein production in plants and stimulate the production of carbon (C)-based defensive compounds (Penuelas and Estiarte, 1997). Therefore, in organic production systems, soil fertility practices have been shown to enhance plant resistance against insects, possibly by increasing $\mathrm{C}$-based defenses and limiting the levels of $\mathrm{N}$ in tissues (Brandt and Molgaard, 2001; Geisler, 1998; Phelan et al., 1995). Conversely, by increasing the availability of soil $\mathrm{N}$ to plants, the ratio of $\mathrm{C}$ to $\mathrm{N}(\mathrm{C}: \mathrm{N})$ in plant tissues may decrease and therefore result in limited production of C-based defenses (Folgarait and Davidson, 1995), especially those that negatively affect insect herbivores (Hsu et al., 2009; Inbar et al., 2001; Le Bot et al., 2009). These effects are generally described by the C:N balance hypothesis (Bryant et al., 1983, 1987).

Previous studies have demonstrated that fertility can affect the chemistry of plants in the brassicaeae family in ways that can impact the feeding and oviposition behaviors of a serious Brassica pest, the diamondback moth (DBM) Plutella xylostella L. (Sarfraz et al., 2009, 2010, 2011). However, it is unknown whether fertilizer inputs induce changes in the production of primary metabolites or defensive phenolic compounds, thus impacting DBM fitness and survival (Hummel et al., 2002; Staley et al., 2010). Moreover, few studies have compared the effects of fertilizer type (organic-based vs. synthetically derived) on plant chemistry and herbivory (Chen et al., 2004; Oelhaf, 1978). Implementing pest management strategies that alleviate insect outbreaks while maximizing crop production may be enhanced by understanding the effects of organic-based vs. synthetically derived fertilizers on plant-insect interactions (Altieri and Nicholls, 2003; Fageria, 2005).

This study compared $\mathrm{N}$ sources from an approved-for-organic-use fish hydrolysate (fish waste enzymatically broken down into peptides) with a conventional fertilizer derived from inorganic salts, which was formulated to have a similar nutrient content as the fish hydrolysate except for $\mathrm{N}$ form. For the fish hydrolysate, the organically bound $\mathrm{N}$ requires mineralization before plant uptake, whereas $\mathrm{N}$ from the conventional fertilizer is readily available to plants (Kristinsson and Rasco, 2000). The specific objectives of this study were to 1) assess the effect of an organic and conventional fertilizer on various pac choi (Brassica rapa subsp. chinensis cv. Mei Qing Choi) chemical composition and growth parameters; and 2) determine the corresponding effects on DBM development and survival. We chose this study system because a prior study revealed that changes in pac choi phenolic content were associated with changes in the growing environment (Zhao et al., 2009). In addition, DBM is a serious insect pest worldwide (Talekar and Lin, 1998).

\section{Materials and Methods} herbivory are associated with plant nutritional quality (proteins and amino acids) and the production of plant chemical defenses (Behmer, 2009; Scriber and Slansky,
Plant material and insect colony. Pac choi (Brassica rapa subsp. chinensis cv. Mei Qing 
Choi) seeds (Johnny's Seeds, Winslow, ME) were germinated in plug trays containing a soilless growing medium, MetroMix 200 (Sun Gro Horticulture, Bellevue, WA) that consisted of Canadian sphagnum peatmoss, vermiculite, perlite, a wetting agent, and trace amounts of N:P:K. Sixty-four 2-week old seedlings were transplanted into $16-\mathrm{cm}$ black plastic containers (one seedling per container) with a soilless growing medium, Natures All Organic Potting Soil (Sun Gro Horticulture, Bellevue, WA) consisting of Canadian sphagnum peatmoss, composted bark, compost, and pumice.

A DBM colony was established at Kansas State University (Manhattan, KS) from a cohort of individuals from Benson Research (Carlisle, PA), which was originally collected in 1988 in Geneva, NY, and maintained on a wheat germ and casein-based diet. The colony was maintained on four to five potted pac choi plants in a $0.60 \times 0.60 \times 0.91-\mathrm{m}$ frame cage covered with 1.4-mm mesh screening in a greenhouse under natural daylight conditions and a temperature range of 20 to $23{ }^{\circ} \mathrm{C}$. The DBM were reared on pac choi for greater than 20 generations before experiments were initiated.

Experimental design and environmental conditions. This study included two greenhouse experiments (spring and fall) conducted from 1 May through 5 June 2010 and 29 Oct. through 6 Dec. 2010. The experiments were conducted using a factorial treatment design with two fertility factors (conventional and organic), two DBM factors (infested and not infested), and sampling time (pre and post) for leachate analysis, in which half of the plants were destructively sampled after one application of fertilizer (pre) and the other half were sampled after three applications of fertilizer (post). Individual potted plants with treatment combinations of fertility, herbivore, and sampling time treatments were arranged in eight blocks as a randomized complete block design for a total of 64 plants. Pots were arranged on two greenhouse benches $(3.6 \times 9.1 \mathrm{~m})$ where plants received natural daylight conditions and a temperature range of 18 to $21^{\circ} \mathrm{C}$.

To maintain uniform growing medium moisture across the blocks, an additional pac choi pot was placed at the corner of each bench, which served as an indicator container to determine when watering was needed. Pac choi plants received $750 \mathrm{~mL}$ of deionized water when the gravimetric weight of the indicator pots decreased by $30 \%$ from container capacity (Altimimi, 2010; Gardner, 1965) in adjacent blocks. Temperature and relative humidity were recorded using a $\mathrm{HOBO}$ data logger (Onset Computer Corp., Pocasset, MA) set at 30-min intervals.

Fertility treatment. The eight plants within each block were randomly assigned to receive either an organic or conventional fertilizer treatment (four organic and four conventional). The organic fertilizer was a soluble fish hydrolysate (Neptune's Harvest, Gloucester, MA) labeled as a $2.2 \mathrm{~N}-4.3 \mathrm{P}-0.3 \mathrm{~K}$ fertilizer and diluted to obtain a target concentration of $167 \mathrm{ppm} \mathrm{N}$. This $\mathrm{N}$ concentration was selected based on previous greenhouse experiments associated with optimal $\mathrm{N}$ rates and pac choi yield (Altimimi, 2010). Three $100-\mathrm{mL}$ diluted hydrolysate samples were submitted for nutrient testing [total $\mathrm{N}$, total phosphorus $(\mathrm{P})$ by potassium $(\mathrm{K})$ persulfate digest, $\mathrm{NO}_{3}{ }^{-}-\mathrm{N}$, and $\mathrm{NH}_{4}{ }^{+}-\mathrm{N}$ in filtered samples by colorimetric analysis and $\mathrm{P}, \mathrm{K}, \mathrm{Mg}$, sulfur $(\mathrm{S})$, iron $(\mathrm{Fe})$, sodium, and chlorine $(\mathrm{Cl})$ in filtered samples analyzed by inductively coupled plasma spectroscopy] by the Soil Testing Laboratory at Kansas State University (Manhattan, KS). The final concentration of the fish hydrolysate composition, based on test results, is shown in Table 1. For fish hydrolysate samples, total $\mathrm{N}$ was $228 \mathrm{mg} \cdot \mathrm{L}^{-1}$ with $13 \% \mathrm{NH}_{4}{ }^{+}-\mathrm{N}$ and $0.2 \% \mathrm{NO}_{3}{ }^{-}-\mathrm{N}$. Based on these results, the conventional soluble fertilizer was formulated using inorganic salts similar to the fish hydrolysate, except for the $\mathrm{N}$ composition, which is presented in Table 1 . The $\mathrm{N}$ composition in the conventional fertilizer was $207 \mathrm{mg} \cdot \mathrm{L}^{-1}$ total $\mathrm{N}$ with $29 \% \mathrm{NH}_{4}{ }^{+}-\mathrm{N}$ and $71 \% \mathrm{NO}_{3}^{-}-\mathrm{N}$. Three applications of either the conventional or organic treatment were applied during each experiment, supplying a total of 210 to $230 \mathrm{mg}$ of $\mathrm{N}$ per container. There were three fertilizer application times: at transplant, $7 \mathrm{~d}$ post-transplant, and $14 \mathrm{~d}$ posttransplant with $330 \mathrm{~mL}$ of fertilizer solution applied each time.

Leachate analysis. Seven days after the first fertilizer application, two organically and two conventionally treated plants from each block were randomly chosen for presampling leachate and plant chemical analysis. Approximately $10 \mathrm{~d}$ after the third fertilizer application, final sampling of leachate, plant chemistry, and shoot biomass were evaluated. Initial and final leachate samples were processed to assess electrical conductivity (EC), $\mathrm{pH}$, and macronutrient levels in the growing medium. EC is a measure of nutrients or dissolved salts in the leachate solution, recorded as $\mathrm{dS} \cdot \mathrm{m}^{-1}$, in which a high EC value indicates a higher concentration of nutrients (Cavins et al., 2008). Containers were sampled using a pour-through method (Cavins et al., 2008), in which containers were irrigated with $750 \mathrm{~mL}$ of deionized water and allowed to equilibrate for $1 \mathrm{~h}$ over a 30-cm diameter clear plastic saucer. After equilibration, another $500 \mathrm{~mL}$ of deionized water was added to the containers to collect $60 \mathrm{~mL}$ of leachate from the saucers. Leachate samples were stored in $100-\mathrm{mL}$ polyethylene vials (Fisher Scientific LLC, Denver, CO). $\mathrm{EC}$ and $\mathrm{pH}$ were measured for each leachate sample (32 initial samples and 32 final samples) using a handheld meter (Hanna Instruments, Model HI98129, Ann Arbor, MI). Leachate samples were submitted to the Kansas State University Soil Testing Laboratory (Manhattan, KS) for analysis of total $\mathrm{N}$ and $\mathrm{P}$, and soluble $\mathrm{K}$ concentrations (ppm) in each sample. After digestion with $\mathrm{K}$ persulfate reagent in an autoclave, samples were analyzed using a Technicon AutoAnalyzer II for P content. An Alpkem Rapid Flow Analyzer (Alpkem Corporation, Clackamas, OR)
Table 1. Final concentration of nutrients applied to each Brassica rapa from three applications of an organic fertilizer, Neptune's Harvest fish hydrolysate (Neptune's Harvest, Gloucester, MA), or three applications of a conventional fertilizer made from an inorganic salt solution computed based on chemical formulas used to compose the solution.

\begin{tabular}{|c|c|c|}
\hline Nutrient (ppm) & Organic & Conventional \\
\hline Total $\mathrm{N}^{\mathrm{y}}$ & $227.7 \pm 14.8$ & 207.4 \\
\hline $\mathrm{NO}_{3}-\mathrm{N}$ & 0.5 & 146.9 \\
\hline $\mathrm{NH}_{4}-\mathrm{N}$ & 30.3 & 60.5 \\
\hline Total P & 232.3 & 209.9 \\
\hline Total K & 60.5 & 60.6 \\
\hline $\mathrm{Ca}$ & 101.7 & 179 \\
\hline $\mathrm{Mg}$ & 11.6 & 11.7 \\
\hline $\mathrm{SO}_{4}-\mathrm{S}$ & 56.7 & 46.1 \\
\hline $\mathrm{Fe}$ & 0.1 & 0.3 \\
\hline $\mathrm{Na}$ & 77.7 & 77.7 \\
\hline $\mathrm{Cl}$ & 32.3 & 32.6 \\
\hline
\end{tabular}

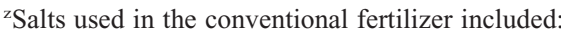
$\mathrm{KNO}_{3}, \mathrm{Ca}\left(\mathrm{NO}_{3}\right)_{2}, \mathrm{MgSO}_{4}, \mathrm{FeETDA}, \mathrm{NaCl}$, $\left(\mathrm{NH}_{4}\right)_{2} \mathrm{HPO}_{4}$, and $\mathrm{NaH}_{2} \mathrm{PO}_{4}$.

yTotal $\mathrm{N}$ is shown as mean \pm SE to demonstrate the variability of $\mathrm{N}$ from three test samples of diluted fish hydrolysate.

$\mathrm{N}=$ nitrogen; $\mathrm{P}=$ phosphorus $; \mathrm{K}=$ potassium $; \mathrm{Ca}=$ calcium; $\mathrm{Mg}=$ magnesium; $\mathrm{Fe}=$ iron; $\mathrm{Na}=$ sodium; $\mathrm{Cl}=$ chlorine .

was used to quantify $\mathrm{NO}_{3}{ }^{-} \mathrm{N}$ in the digested samples using the cadmium reduction method. Potassium content was determined by filtering the samples through \#642 filter paper before analysis using a Flame Atomic Absorption Spectrophotometer 3110 (Perkin Elmer Corporation, Norwalk, CT).

Herbivore treatment. After the presampling for leachate analysis was conducted, four plants in each block, two per fertilizer treatment, were infested with 20 , second instar DBM larvae $7 \mathrm{~d}$ after transplanting. Infestation involved the individual transfer of larvae from colony plants to the same leaf in the middle whorl of experimental plants using a fine-tipped paintbrush. To confine larvae to plants, plants were caged using $0.6 \times 0.6 \mathrm{~m}$ nylon (2 $\mathrm{mm}$ mesh), which was fastened around the base of each infested pac choi plant with wooden clothespins.

At the initiation of adult emergence, moths were collected daily using the "bellows method" (Johnson, 2011). Adults were then sexed and individually weighed to the nearest $0.001 \mathrm{mg}$ using an electronic balance. Male DBM were identified by the distinctive diamond-shaped patterning on the forewings, which is less evident on females (Muhamad et al., 1994; Shirai, 1993). During the emergence period, some female moths mated and laid eggs. Therefore, experiments were ended before eggs hatched and first instars began feeding, which could have affected the results. At the time of the final plant sample, counts of each larval instar as well as pupae were recorded.

Plant chemical analysis. Shoot biomass of aboveground plant parts were measured as fresh weight to the nearest $0.001 \mathrm{mg}$ for all plants. Plant height and leaf length $(\mathrm{cm})$ of one leaf in the middle whorl were recorded along with the number of leaves for all plants. 
For phenolic content analysis, two leaves were excised from the middle whorl (youngest, fully expanded leaves) of pac choi plants. To avoid bias from diel cycling of plant nutrients and phenolics, samples were processed between 6:00 and 8:00 AM for both experiments (You and Yang, 2001). Although greenhouse light intensities varied during the 6:00 and 8:00 AM sampling time between spring and fall experiments, the difference in light intensity was not expected to impact the comparison of plant responses between experiments (C.B. Rajeshaker, personal communication). To avoid a chemical response in plant tissue resulting from wounding by excising leaf tissue, leaf material was immediately frozen in liquid nitrogen and stored at $-20{ }^{\circ} \mathrm{C}$ for $\approx 1$ week until used in the analyses. For moisture content and C:N ratio, two additional leaves from the middle whorl of each plant were excised, weighed, placed in \#2 brown paper bags, and stored at $-20{ }^{\circ} \mathrm{C}$ until analyzed. For $\mathrm{C}$ and $\mathrm{N}$ levels, leaf material was dried in a forced-air oven set at $68{ }^{\circ} \mathrm{C}$ for $72 \mathrm{~h}$ and then ground in a stainless steel Wiley mill to pass through a 20 mesh screen (Scientific Apparatus, Philadelphia, PA).

Total percent $\mathrm{C}$ and $\mathrm{N}$ (both free and structural forms) were assessed from the ground tissue using a dry combustion procedure conducted by the Kansas State Soil Testing Laboratory (Manhattan, KS) through a TruSpec CN analyzer (LECO Corporation, St. Joseph, MO). Concentrations of total percent leaf $\mathrm{P}, \mathrm{K}, \mathrm{Ca}, \mathrm{Mg}, \mathrm{S}, \mathrm{Fe}$, copper $(\mathrm{Cu})$, manganese $(\mathrm{Mn})$, and zinc $(\mathrm{Zn})$ from a 0.5 -g sample of ground tissue were analyzed by an inductively coupled plasma spectrometer (SPECTRO Analytical Instruments, Kleve, Germany) after nitric acid digestion. Moisture content of the leaf tissue was assessed based on the difference between wet and dry weights of the leaf samples. Total phenolic content was analyzed using the modified Folin-Ciocalteu method (Oh, 2008; Pennycooke et al., 2005; M-.M. Oh, personal communication). Modifications to this method included the use of $0.5 \mathrm{~g}$ of frozen leaf tissue, which was ground and combined with $3 \mathrm{~mL}$ of $80 \%(\mathrm{v} / \mathrm{v})$ acetone. A $1-\mathrm{mL}$ sample of extract solution was then used for spectrophotometer absorbance reading (Pennycooke et al., 2005). A gallic acid standard curve was prepared using $1 \mathrm{mg} \cdot \mathrm{mL}^{-1}$ gallic acid (Acros Organics, Geel, Belgium) in $80 \%(\mathrm{v} / \mathrm{v})$ acetone from a stock solution. Total phenolics were reported as gallic acid equivalents/g fresh weight tissue.

The extraction of individual phenolics from the pac choi leaves is described by Nicolle et al. (2004) with minor modifications (Oh, 2008; Oh and Rajashekar, 2009). Modifications included the use of $1 \mathrm{~g}$ of frozen leaf tissue, ground, and combined with $25 \mathrm{~mL}$ of $70 \%$ methanol. This extract solution was placed for $1 \mathrm{~min}$ in a water bath $\left(80^{\circ} \mathrm{C}\right)$, agitated on a shaker plate for $1 \mathrm{~h}$, and filtered using No. 1 paper (Whatman, Kent, U.K.). The filtered extract $(9 \mathrm{~mL})$ was then evaporated to dryness by speed vacuum (Savant
SVC-100H Speed Vac Concentrator; Midland, MI) under reduced pressure at $43{ }^{\circ} \mathrm{C}$, then filtered through a $0.45-\mu \mathrm{m}$ ascrodisc filter (Millex; Millipore Corporation, Bedford, MA), and re-suspended in $5 \mathrm{~mL}$ of $70 \%$ methanol. A $5-\mu \mathrm{L}$ aliquot of the concentrated extract was then diluted in methanol and used in high-performance liquid chromatography for identification of the designated phenolics: chlorogenic, p-coumaric, caffeic, sinapic and ferulic acids, quercetin3-O-glucoside, and luteolin-7-O-glucoside. Peaks for each phenolic compound were quantified and identified at $330 \mathrm{~nm}$ by comparing them with standard compounds of chlorogenic, p-coumaric, caffeic, sinapic and ferulic acids, and quercetin-3-O-glucoside (Sigma-Aldrich, St. Louis, MO) and luteolin-7-O-glucoside (Indofine Chemical Company, Inc., Hillsborough, NJ). These specific compounds were selected based on prior experiments with pac choi and phenolic content (M-.M. Oh, personal communication). High-performance liquid chromatography was performed by the Ruminant Nutrition Laboratory, Kansas State University (Manhattan, KS). Of the phenolics assayed, only chlorogenic, sinapic, and p-coumaric acids were detected in the leaf samples. Specific phenolic data are reported in $\mathrm{mg} / 100 \mathrm{~mL}$ of methanolic extract.

Herbivory and herbivore response. The amount of herbivory was measured based on percent leaf area removed by feeding on plants infested with DBM larvae. For the herbivory measurement, digital images were taken of two leaves from the middle whorl (youngest, fully expanded leaves) using a camera (PowerShot SD1000; Canon, Tokyo, Japan). A photo-imaging analysis program, APS Assess Version 2.0 (APS Press, St. Paul, $\mathrm{MN}$ ), was used to quantify total leaf area and total leaf area removed (Dudt and Shure, 1994; Lamari, 2002). Because samples contained a variable number of mixed instars, larval feeding equivalents were also used to compare herbivory between treatments. Larval feeding equivalents were calculated by dividing the percentage total leaf area consumed by the cumulative number of relative feeding equivalents. Feeding equivalents were obtained by multiplying the number of each larval instar counted on plants by the estimated relative proportion of leaf tissue required for each larval instar to complete development. Because the relative instar consumption values are unknown for DBM, we estimated consumption from those reported by Pratissoli et al. (2002) for Erinnyis ello (Lepidoptera: Sphingidae). Both species are defoliating caterpillars that increase their amount of consumption incrementally from the first to fourth instar (Bellotti et al., 1992; Talekar and Lin, 1998). This procedure resulted in the following formula:

$$
\mathrm{PC}=\frac{\mathrm{PLFR}}{\sum(\mathrm{IN} \times \mathrm{CR})}
$$

where $\mathrm{PC}=$ percentage consumption per insect per plant, PLFR $=$ percentage total leaf area removed, $\mathrm{IN}=$ number of each instar, and $\mathrm{CR}=$ standardized consumption values for each instar (third instar $=3$, fourth instar $=$ 8 , and pupa $=16$ ).

Because there was a mixture of DBM life stages (age classes) present at the end of the experiment, mean developmental rates could not be conveniently calculated. Instead, estimates of cohort development were computed and compared between fertility treatments using degree-days (DD) as a standardized unit of comparison. Specifically, the number of individuals in each instar per plant and per treatment at the end of the experiment was multiplied by the number of DD required for that life stage to complete development based on data from Ansari et al. (2010) for DBM feeding on Brassica rapa. The total number of DD was then summed and the average number DD for the cohort was computed as follows:

$$
\mathrm{CDD}=\frac{\sum(\mathrm{IN} \times \mathrm{DD})}{\sum \mathrm{TI}}
$$

where $\mathrm{CDD}=$ average cohort $\mathrm{DD}, \mathrm{IN}=$ number of each instar, DD = the number of DD needed for that life stage to complete development (third instar $=221.75$, fourth instar $=159.25$, pupa $=83.44$, and adult $=0$ ), and $\mathrm{TI}=$ total number of instars present Second instars were not present on plants at the end of each experiment; therefore, they were not included in the analysis. The proportion of DBM in each life stage did not differ significantly between fertility treatments within an experiment. Therefore, percent survival could be compared directly within the experiments. Percent cohort survival was computed as the sum of emerged adults and remaining larvae on plants at the conclusion of the experiment divided by the initial number of larvae (20 per plant).

Statistical analysis. Leachate N, P, K, and EC values were $\log _{10}$-transformed to normalize the data before analyses. Percentage data for plants (leaf tissue $\mathrm{N}, \mathrm{C}, \mathrm{P}, \mathrm{K}, \mathrm{Ca}, \mathrm{Mg}, \mathrm{S}$, and moisture content) and DBM (consumption as larval feeding equivalents and cohort survival) were arsine-transformed before analysis to normalize the data. All data presented are non-transformed.

Data pertaining to plant, insect, and leachate responses were subjected to a mixed model analysis of variance (ANOVA) using the PROC MIXED procedure (SAS Institute, 2002) with experiment (spring and fall), fertility (organic and conventional), and herbivory (plants with and without DBM) as the main effects and block as the random effect Tests for significance were conducted for all main effects and for the two-way interactions of experiment $\times$ fertility and fertility $\times$ herbivore for plant and insect variables; and the effects of sampling time, experiment, fertility, experiment $\times$ fertility, and experiment $\times$ fertility $\times$ sampling time were used to test leachate variables. For leachate variables having significant experiment $X$ sampling time interactions, means were then sliced to show significance for each main effect in a partitioned analysis of the least square means for the interaction (SAS Institute, 2002). The LS MEANS statement 
Table 2. Analysis of variance (ANOVA) values for Brassica rapa response variables for block $(\mathrm{n}=8)$, experiment (spring and fall), fertility treatment (conventional and organic), and herbivory (with and without Plutella xylostella).

\begin{tabular}{|c|c|c|c|c|c|c|c|c|c|c|c|c|c|c|c|c|}
\hline \multirow[b]{2}{*}{ Plant variables ${ }^{z}$} & \multicolumn{4}{|c|}{ Block } & \multicolumn{4}{|c|}{ Expt. } & \multicolumn{4}{|c|}{ Fertility } & \multicolumn{4}{|c|}{ Herbivory } \\
\hline & $\mathrm{N}^{\mathrm{w}}$ & $\mathrm{df}$ & $\mathrm{F}$ & $P$ & $\mathrm{~N}$ & $\mathrm{df}$ & $\mathrm{F}$ & $P$ & $\mathrm{~N}$ & $\mathrm{df}$ & $F$ & $P$ & $\mathrm{~N}$ & $\mathrm{df}$ & $\mathrm{F}$ & $P$ \\
\hline Leaf\% C & 62 & 7 & 1 & 0.44 & 62 & 1 & 113.69 & $<0.001$ & 62 & 1 & 0.89 & 0.34 & 62 & 1 & 0.21 & 0.64 \\
\hline Leaf \% P & 62 & 7 & 0.57 & 0.77 & 62 & 1 & 55.49 & $<0.001$ & 62 & 1 & 4.29 & 0.04 & 62 & 1 & 2.46 & 0.12 \\
\hline Leaf \% Ca & 62 & 7 & 0.69 & 0.68 & 62 & 1 & 22.1 & $<0.001$ & 62 & 1 & 0.16 & 0.69 & 62 & 1 & 5.72 & 0.02 \\
\hline Leaf \% Mg & 62 & 7 & 0.18 & 0.98 & 62 & 1 & 4.27 & 0.04 & 62 & 1 & 0.07 & 0.79 & 62 & 1 & 3.72 & 0.05 \\
\hline Leaf \% S & 62 & 7 & 1.49 & 0.19 & 62 & 1 & 9.52 & 0.003 & 62 & 1 & 0.28 & 0.6 & 62 & 1 & 1.27 & 0.26 \\
\hline Leaf Mn (ppm) & 62 & 7 & 2.24 & 0.04 & 62 & 1 & 23.94 & $<0.001$ & 62 & 1 & 0.54 & 0.22 & 62 & 1 & 1.7 & 0.19 \\
\hline Leaf Zn (ppm) & 62 & 7 & 1.31 & 0.26 & 62 & 1 & 88.79 & $<0.001$ & 62 & 1 & 2.33 & 0.13 & 62 & 1 & 0.55 & 0.46 \\
\hline Plant height $(\mathrm{cm})$ & 63 & 7 & 0.001 & 1 & 63 & 1 & 14.32 & $<0.001$ & 63 & 1 & 1.44 & 0.23 & 63 & 1 & 1.79 & 0.18 \\
\hline Leaf number & 63 & 7 & 0.001 & 1 & 63 & 1 & 66.11 & $<0.001$ & 63 & 1 & 0.1 & 0.75 & 63 & 1 & 12.07 & 0.001 \\
\hline Leaf length (cm) & 63 & 7 & 0.001 & 1 & 63 & 1 & 0.07 & 0.78 & 63 & 1 & 0.78 & 0.38 & 63 & 1 & 5.81 & 0.01 \\
\hline Shoot biomass (g) & 63 & 7 & 0.06 & 0.99 & 63 & 1 & 48.3 & $<0.001$ & 63 & 1 & 0.001 & 0.98 & 63 & 1 & 7.13 & 0.01 \\
\hline Percent moisture content & 62 & 7 & 2.13 & 0.05 & 62 & 1 & 1.86 & 0.17 & 62 & 1 & 0.12 & 0.73 & 62 & 1 & 0.26 & 0.61 \\
\hline
\end{tabular}

${ }^{\text {z} B o l d e d ~ v a l u e s ~ a r e ~ s i g n i f i c a n t ~ a t ~} P \leq 0.05$.

${ }^{\mathrm{y}}$ Total phenolic (TP) content is reported as gallic acid equivalents/g fresh weight of plant tissue.

${ }^{\mathrm{x}}$ Concentrations of specific phenolic compounds are reported as $\mathrm{mg} / 100 \mathrm{~mL}$ of methanolic extract.

wumber of plants having detectable levels of compounds out of the 64 plants used in analysis.

$\mathrm{N}=$ nitrogen; $\mathrm{C}=$ carbon; $\mathrm{P}=$ phosphorus; $\mathrm{K}=$ potassium; $\mathrm{Ca}=$ calcium; $\mathrm{Mg}=$ magnesium; $\mathrm{S}=\mathrm{sulfur} ; \mathrm{Cu}=$ copper; Fe $=$ iron; $\mathrm{Mn}=$ manganese; $\mathrm{Zn}=$ zinc .

Table 3. Mean $( \pm \mathrm{SE})$ differences in Brassica rapa response variables between the spring and fall experiments across plants with and without Plutella xylostella. ${ }^{2}$

\begin{tabular}{lrr}
\hline Plant variables & \multicolumn{1}{c}{ Spring } & \multicolumn{1}{c}{ Fall } \\
\hline Total \% N & $3.32 \pm 0.18 \mathrm{~b}^{\mathrm{y}}$ & $4.54 \pm 0.18 \mathrm{a}$ \\
Total \% C & $39.06 \pm 0.15 \mathrm{~b}$ & $41.56 \pm 0.17 \mathrm{a}$ \\
Leaf \% P & $0.52 \pm 0.03 \mathrm{~b}$ & $0.72 \pm 0.02 \mathrm{a}$ \\
Leaf \% K & $1.37 \pm 0.10 \mathrm{~b}$ & $2.80 \pm 0.16 \mathrm{a}$ \\
Leaf S (ppm) & $0.56 \pm 0.04 \mathrm{~b}$ & $1.27 \pm 0.05 \mathrm{a}$ \\
Leaf Cu (ppm) & $0.73 \pm 0.14 \mathrm{~b}$ & $3.52 \pm 0.40 \mathrm{a}$ \\
Leaf Fe (ppm) & $166.9 \pm 10.14 \mathrm{a}$ & $88.43 \pm 3.12 \mathrm{~b}$ \\
Leaf Mn (ppm) & $114.96 \pm 6.5 \mathrm{~b}$ & $171.51 \pm 10.84 \mathrm{a}$ \\
Leaf Zn (ppm) & $41.80 \pm 2.33 \mathrm{~b}$ & $74.74 \pm 2.57 \mathrm{a}$ \\
Percent moisture & $96.44 \pm 0.14 \mathrm{a}$ & $96.23 \pm 0.10 \mathrm{~b}$ \\
$\quad$ & &
\end{tabular}

${ }^{\mathrm{z}} \mathrm{A}$ total of 64 plants were used in the analysis.

${ }^{\mathrm{y}}$ Means followed by a different letter within a row are significantly different at $P \leq 0.05$ (Fisher's protected least significant difference)

${ }^{\mathrm{x}}$ Indicates there was a significant difference between the organic and conventional fertility treatments $(P \leq 0.05)$.

$\mathrm{N}=$ nitrogen; $\mathrm{C}=$ carbon; $\mathrm{P}=$ phosphorus; $\mathrm{K}=$ potassium; $\mathrm{S}=$ sulfur; $\mathrm{Cu}=$ copper; $\mathrm{Fe}=$ iron; $\mathrm{Mn}=$ manganese; $\mathrm{Zn}=$ zinc.

Table 4. Mean ( $\pm \mathrm{SE})$ differences for Brassica rapa variables between experiments (spring and fall) and herbivory (with and without Plutella xylostella).

\begin{tabular}{lccccc}
\hline & \multicolumn{2}{c}{ Spring } & & \multicolumn{2}{c}{ Fall } \\
\cline { 2 - 3 } \cline { 5 - 6 } Plant variables & No herbivore & Herbivore & & No herbivore & Herbivore \\
\hline Leaf \% $\mathrm{Ca}^{\mathrm{z}}$ & $0.46 \pm 0.40 \mathrm{~b}^{\mathrm{x}}$ & $0.66 \pm 0.28 \mathrm{a}$ & & $1.10 \pm 0.24 \mathrm{a}$ & $1.24 \pm 0.19 \mathrm{a}^{\mathrm{w}}$ \\
Leaf \% Mg & $0.54 \pm 0.29 \mathrm{~b}$ & $0.67 \pm 0.16 \mathrm{a}$ & & $0.70 \pm 0.18 \mathrm{a}$ & $0.81 \pm 0.17 \mathrm{a}^{\mathrm{w}}$ \\
Plant height $(\mathrm{cm})^{\mathrm{y}}$ & $14.68 \pm 1.30 \mathrm{a}$ & $14.43 \pm 1.67 \mathrm{a}^{\mathrm{w}}$ & & $13.50 \pm 1.36 \mathrm{a}$ & $13.12 \pm 1.25 \mathrm{a}$ \\
Leaf number & $19.50 \pm 3.77 \mathrm{a}$ & $16.87 \pm 3.26 \mathrm{~b}^{\mathrm{w}}$ & & $13.93 \pm 1.48 \mathrm{a}$ & $12.31 \pm 1.44 \mathrm{a}$ \\
Shoot biomass $(\mathrm{g})^{\mathrm{y}}$ & $141.93 \pm 39.86 \mathrm{a}$ & $119.93 \pm 33.68 \mathrm{~b}^{\mathrm{w}}$ & & $92.72 \pm 20.67 \mathrm{a}$ & $82.15 \pm 17.30 \mathrm{a}$ \\
\hline
\end{tabular}

${ }^{2} \mathrm{~N}=15$ plants used in analysis.

${ }^{\mathrm{y}} \mathrm{N}=16$ plants used in analysis.

${ }^{\mathrm{x}}$ Means followed by a different lower case letter within a row for each experiment indicates a significant difference in herbivore treatment at $P \leq 0.05$ (Fisher's protected LSD).

wIndicates that means across herbivore treatments are significantly different between experiments at $P \leq 0.05$ (Fisher's protected LSD).

$\mathrm{Ca}=$ calcium; $\mathrm{Mg}=$ magnesium; $\mathrm{LSD}=$ least significant difference.

(SAS Institute, 2002) and Fisher's protected least significant difference (LSD) were used to make pairwise treatment comparisons. Greenhouse environmental variables associated with light intensity, temperature, and relative humidity were also analyzed between experiments using an unpaired Student's $t$ test.
Development, larval consumption, and survival data for either fertility treatment in each block $(n=8)$ were subjected to ANOVA using a PROC MIXED model for the effects of fertility, experiment, and the fertility $X$ experiment interaction. The LS MEANS statement (SAS Institute, 2002) and Fisher's protected LSD were used to make pairwise treatment comparisons.

To determine if experiment and fertility were correlated with various plant and insect responses, multiple regression analyses were performed using a best-subsets analysis (Minitab Inc., State College, PA) (Dallal, 2007) and the PROC REG procedure (SAS Institute, 2002). Multiple regressions applied a stepwise, backward elimination procedure (SAS Institute, 2002). Multiple regression results were assessed for best fit (linear or quadratic) in MINITAB using fitted line plots.

To determine if experiment and fertility were correlated with various plant and insect responses, multiple regression analyses were performed using a best-subsets analysis (Minitab Inc.) (Dallal, 2007) and the PROC REG procedure (SAS Institute, 2002). Multiple regressions applied a stepwise, backward elimination procedure (SAS Institute, 2002). Multiple regression results were assessed for best fit (linear or quadratic) in MINITAB using fitted line plots.

\section{Results}

Plant response variables. There were no significant differences in the plant response variables between the fertility treatments in either experiment (Table 2) with the exception of percent leaf $\mathrm{P}$ and the concentration of p-coumarin (Table 2). In both experiments, the percentage of leaf $\mathrm{P}$ was significantly higher for the conventional fertility treatment $(0.71 \% \pm 0.02 \%)$ compared with the organic 
fertility treatment $(0.63 \% \pm 0.02 \%)$. The concentration of p-coumarin was significantly higher in the organic fertility treatment $(12.93 \pm 1.18 \mathrm{mg} / 100 \mathrm{~mL})$ compared with the conventional treatment $(6.25 \pm 0.58$ $\mathrm{mg} / 100 \mathrm{~mL}$ ). Detectable concentrations of p-coumarin were found in only 19 of 32 (59\%) samples in the spring experiment and six of $32(18 \%)$ samples in the fall experiment. The experiment $\times$ fertility and fertility $\times$ herbivore interactions were not significant for any plant response variables $(P>0.05)$, indicating that the differences in plant responses between the fertility treatments were similar for the two experiments and for plants with and without DBM.

In general, percent leaf $\mathrm{N}, \mathrm{C}, \mathrm{P}, \mathrm{K}, \mathrm{Ca}$, $\mathrm{Mg}, \mathrm{S}$, and ppm $\mathrm{Cu}, \mathrm{Mn}$, and $\mathrm{Zn}$ were higher in the fall experiment than the spring experiment, whereas ppm Fe, plant height, shoot biomass, and leaf number were all generally lower in the fall experiment (Tables 3 and 4). Concentrations of specific phenolics were significantly higher in the fall experiment compared with spring $(P \leq 0.05)$, whereas total phenolic content was significantly higher in the spring than fall experiment $(P \leq 0.05)$ (Fig. 1).

Herbivory. There was a significant experiment $\times$ herbivore interaction associated with percent leaf $\mathrm{Ca}(F=5.53$; df $=1,59$; $P=0.02)$. When leaf $\mathrm{Ca}$ was sliced for the effect of experiment, differences in $\mathrm{Ca}$ between spring and fall were significant $(P \leq$ $0.05)$. Slicing for the effect of herbivory (presence or absence of DBM), leaf Ca was higher in plants with DBM than in plants without DBM $(P \leq 0.0001)$ (Table 4). Herbivory also significantly affected percent leaf $\mathrm{Mg}(F=4.46 ; \mathrm{df}=1,59 ; P=$ $0.03)$ and shoot biomass $(F=6.21 ; \mathrm{df}=1$, $53 ; P=0.01)$, where leaf $\mathrm{Mg}$ was significantly higher in plants with DBM than in plants without DBM, and shoot biomass was significantly greater in plants without DBM compared with plants with DBM (Table 4).

Diamondback moth variables. Diamondback moth development was affected by the fertility treatments $(F=4.6 ; \mathrm{df}=1,32 ; P=$ $0.04)$. Cohort development was significantly faster on plants receiving the conventional fertility treatment $(83.9 \pm 8.9 \mathrm{DD})$ compared with plants receiving the organic fertility treatment $(105.3 \pm 6.6$ DD). Diamondback moth development was also affected by experiment $(F=17.13$; df $=1,32 ; P=0.005)$ with development significantly faster in the fall (73.55 $\pm 9.02 \mathrm{DD})$ than the spring experiment $(112.0 \pm 20.46$ DD). The experiment $X$ fertility interaction was not significant $(P>$ $0.05)$. Leaf consumption, based on larval feeding equivalents, was not significantly different for experiment, fertility treatment, or the experiment $\times$ fertility interaction $(P>0.05)$.

Percent DBM survival was significantly affected by fertility treatment $(F=5.4 ; \mathrm{df}=1$, $32 ; P=0.02)$. Specifically, for both the spring and fall experiments, percent survival was significantly higher on plants receiving the conventional fertility treatment $(64 \% \pm 0.04 \%)$
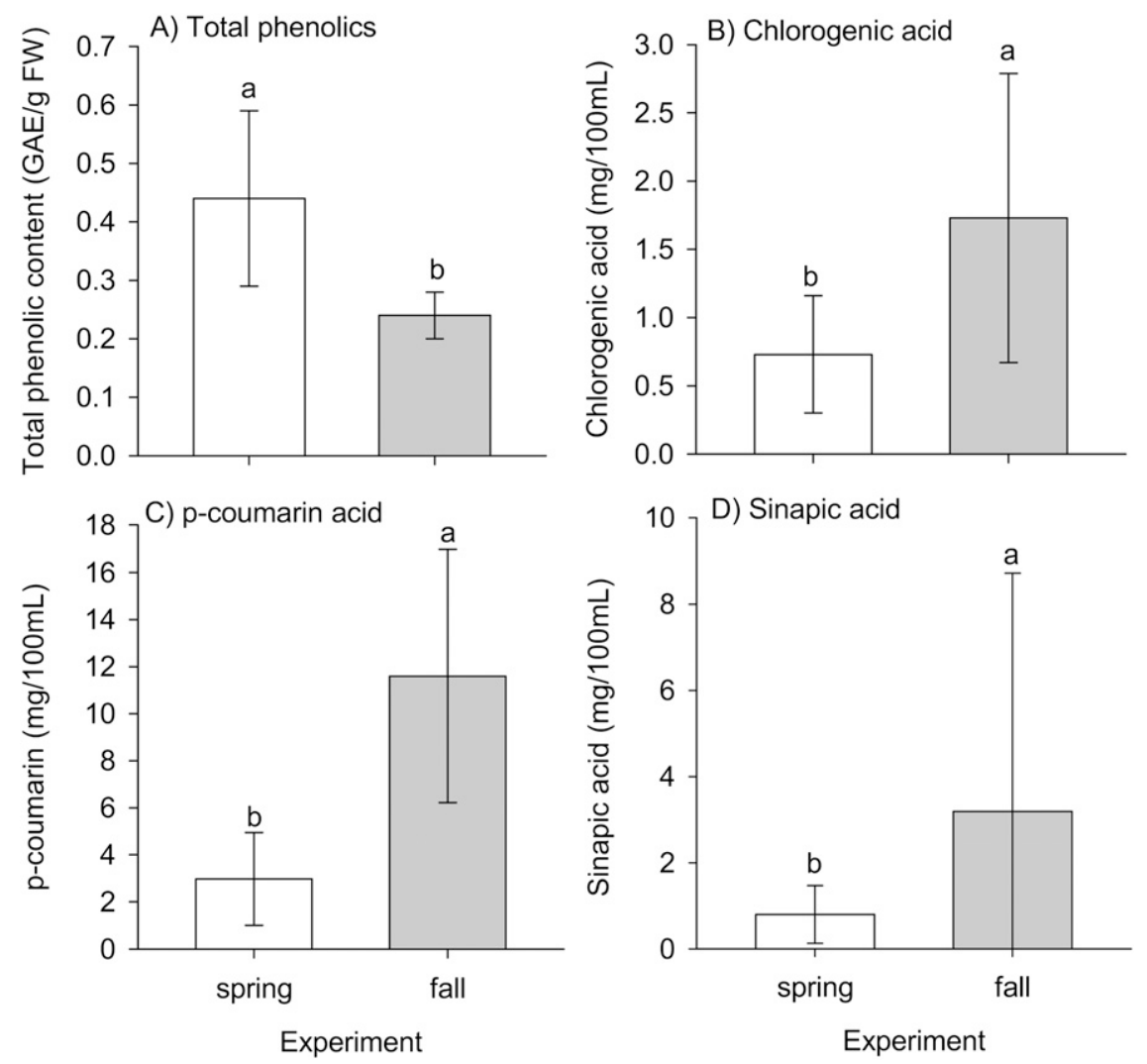

Fig. 1. Mean ( \pm SE) (A) total phenolics, (B) chlorogenic acid, (C) p-coumarin, and (D) sinapic acid measured in gallic acid equivalents (GAE) in Brassica rapa for spring and fall experiments. There were 32 plants sampled with four plants in each of eight blocks. Vertical bars with a common letter are not significantly different between experiments as determined by Fisher's protected least significant difference (LSD) test at $P \leq 0.05$.

compared with plants receiving the organic fertility treatment $(46 \pm 0.05 \%)$. Percent survival was also significantly affected by experiment $(F=5.37$; df $=1,32 ; P=0.02)$ although the experiment $\times$ fertility interaction was not significant $(F=1.35, \mathrm{df}=1,16$; $P=0.25$ ), which suggests that the effects of fertility and time the experiment was conducted on survival were independent. Regression analysis revealed that DBM survival varied significantly with leaf $\mathrm{Mg}$, in which survival was negatively related to leaf $\mathrm{Mg}$ at concentrations greater than $0.6 \%$ in the fall experiment $(F=6.79$; df $=1,16 ; P=0.02)$. Changes in leaf $\mathrm{Mg}$ may be responsible for the high percentage variation in survival for the fall experiment $\left(R^{2}=97 \%\right)$ (Fig. 2). However, the regression of survival and leaf $\mathrm{Mg}$ was not significant in the spring experiment $(F=4.07$; $\mathrm{df}=1,16 ; P=0.06$ ).

Fertility treatment did not significantly affect male or female DBM body weights nor was there a significant experiment $\times$ fertility interaction $(P>0.05)$. Female body weights were significantly affected by experiment $(F=12.43 ; \mathrm{df}=1,16 ; P=0.002)$, in which body weights were higher in the spring experiment $(4.87 \pm 1.10 \mathrm{mg})$ than the fall experiment $(2.73 \pm 1.50 \mathrm{mg})$. Male body weights were not significantly affected by experiment $(P>0.05)$.

Leachate variables. There were no significant differences in leachate $\mathrm{N}, \mathrm{P}, \mathrm{K}, \mathrm{pH}$, and $\mathrm{EC}$ between the fertility treatments (Table 5).
However, leachate $\mathrm{N}, \mathrm{P}, \mathrm{K}, \mathrm{pH}$, and EC were significantly affected by sampling time (Table 5), in which all variables were significantly higher at pre-sample (before introducing DBM) compared with the post-sample (end of experiment). For leachate P, the preand post-sample concentrations (mean $\pm \mathrm{SE}$ ) were $30.8 \pm 1.7 \mathrm{ppm}$ and $18 \pm 2.5 \mathrm{ppm}$, respectively. For the other leachate variables $(\mathrm{N}, \mathrm{K}, \mathrm{pH}$, and $\mathrm{EC})$, there was a significant experiment $\times$ sampling time interaction (Table 5), indicating that the magnitude of difference between the pre- and post-samples was not the same for the spring and fall experiments. Slicing tests for main effects (experiment and sampling time) were used to determine the significance of each effect while holding the other constant. Slicing for the effect of experiment across sampling times revealed that leachate $\mathrm{N}, \mathrm{K}$, and $\mathrm{pH}$ were all significantly different between the spring and fall experiments $(P<0.0001)$, whereas slicing for sampling times across experiments revealed that leachate $\mathrm{N}$ and $\mathrm{K}$ were not significantly different between sampling times $(P>0.05)$ but leachate $\mathrm{pH}$ was $(P<0.0001)$. For leachate EC, slicing for sampling times across experiments showed that the EC was significantly different across sampling times between experiments $(P<$ $0.0001)$, and the EC was significantly different between sampling times when experiment was held constant $(P<0.001)$. Using pairwise treatment comparisons, leachate $\mathrm{N}$ 
and $\mathrm{K}$ were significantly greater at the presampling time in the spring experiment, leachate $\mathrm{pH}$ was significantly higher in the spring post-sampling time, and leachate EC was significantly higher at the spring presampling time compared with other sampling time and experiment combinations (Fig. 3).

Greenhouse environmental conditions (light intensity, temperature, and relative humidity) were significantly higher in the spring experiment than in the fall experiment. Greenhouse conditions were significantly different between experiments, including light intensity $(\mathrm{t}=-8.69, \mathrm{df}=856, P \leq 0.001)$, which was higher in the spring experiment $(18,324 \pm 376$ lumens $/ \mathrm{ft}^{2}$ ) compared with the fall experiment $\left(12,825 \pm 505\right.$ lumens $\left./ \mathrm{ft}^{2}\right)$. Temperature was also significantly $(\mathrm{t}=-18.62, \mathrm{df}=2613, P \leq$ $0.001)$ higher in the spring experiment $(25 \pm$ $0.1^{\circ} \mathrm{C}$ ) compared with the fall experiment $\left(21 \pm 0.1^{\circ} \mathrm{C}\right)$; and percent relative humidity was significantly higher $(\mathrm{t}=-39.78, \mathrm{df}=$ $2613, P \leq 0.001)$ in the spring experiment $(59 \% \pm 0.4 \%)$ than the fall experiment $(33 \% \pm 0.3 \%)$.

\section{Discussion}

In this study, the type of fertilizer used had no effect on any of the leachate variables and only a minimal effect on pac choi chemistry. With respect to plant responses, percent leaf $\mathrm{P}$ was significantly higher in the conventional fertility treatment than the organic fertility treatment in both experiments. Other

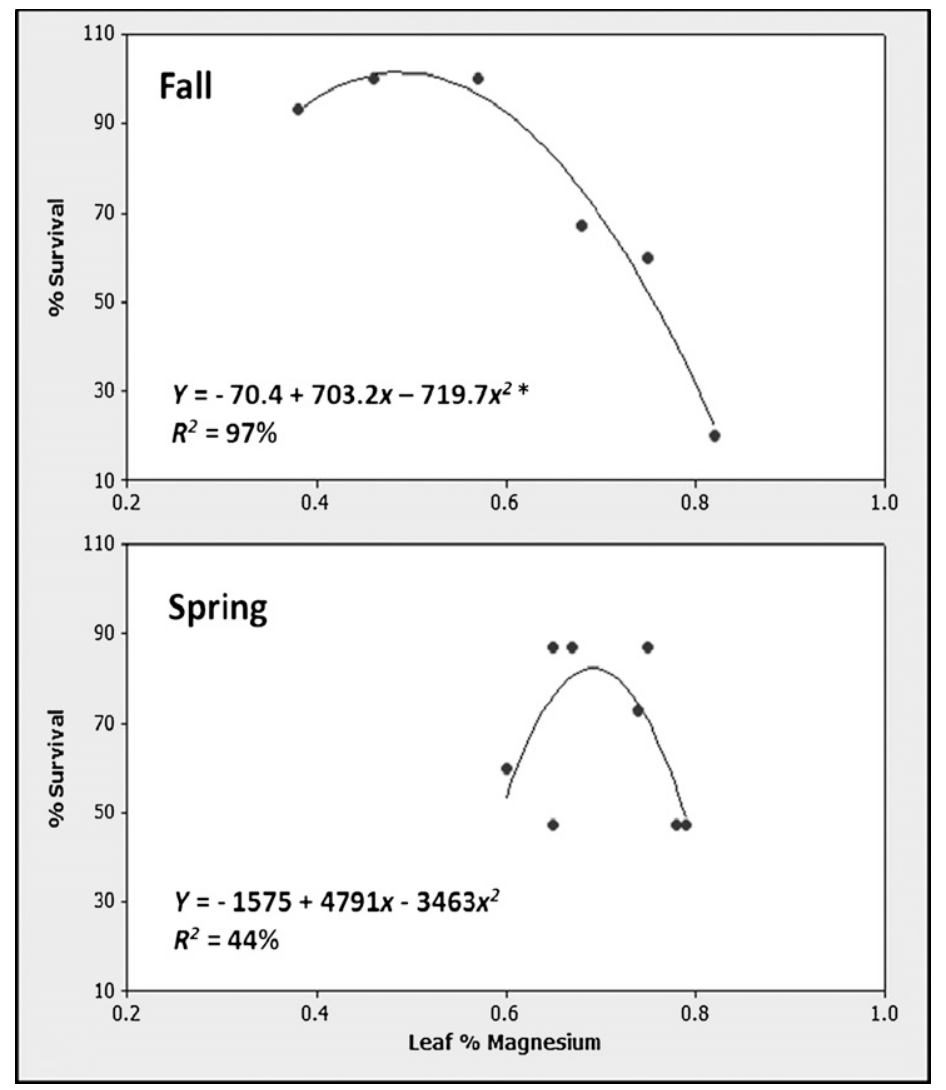

Fig. 2. Relationship between percent survival of the diamondback moth, Plutella xylostella, and leaf percent (\%) magnesium for Brassica rapa in the spring and fall experiments. The best-fit relationships (quadratic) are shown along with line equations and coefficients of determination. Relationships marked with an asterisk $(*)$ are significant at $P \leq 0.05$. Points represent survival per block $(\mathrm{n}=4)$ used in the analysis.

studies examining plant $\mathrm{P}$ content in relation to different types of fertilizers are not known for pac choi. The protein competition model proposed by Jones and Hartley (1999) suggests that $\mathrm{P}$ has a limiting effect on plant growth and $\mathrm{C}$ fixation through reduced phosphorylation. Therefore, it might be expected that the higher levels of $\mathrm{P}$ in conventionally fertilized pac choi may have limited available $\mathrm{C}$ for use in accumulating phenolics. However, there were no differences in total phenolic content between the fertility treatments and no differences in any of the plant growth responses. These results differ from Zhao et al. (2009), who examined nutrient and phenolic contents in greenhouse-grown pac choi (Brassica rapa subsp. chinensis 'Mei Qing Choi') and compared an organic fish hydrolysate fertilizer with a conventional fertilizer (inorganic salt solution formulated similar to fish hydrolysate). They found increased phenolic contents in plants that received the fish hydrolysate fertilizer compared with plants that received the conventional treatment. It must be noted, however, that Zhao et al. (2009) applied higher rates of $\mathrm{N}$ and added a slow-release compost amendment to the fish hydrolysate treatment, which may have immobilized and limited $\mathrm{N}$ provided to plants by the fish hydrolysate. Based on the C:N balance hypothesis (Bryant et al., 1983), it would be expected that leaf C and phenolic content would increase when $\mathrm{N}$ resources were limited for plant growth and development.

In this study, the organic fertility treatment was designed to create a limited $\mathrm{N}$ supply for pac choi plants relative to the conventional fertility treatment. However, based on the plant responses, it appeared that $\mathrm{N}$ was not actually a limiting factor in the organic fertility treatment nor were there differences in leaf $\mathrm{C}$ and phenolic content between the treatments. The similarities between the fertilizer treatments in this study may be attributed to rapid mineralization of organically bound $\mathrm{N}$, which is common for animal-based fertilizers (Hartz and Johnstone, 2006). Moreover, some greenhouse studies have reported similar plant chemistries and growth responses in plants receiving fishbased and synthetically based fertilizers (Aung and Flick, 1980; Emino, 1981).

Diamondback moth herbivory impacted plant chemistry with larval feeding, possibly increasing the levels of leaf $\mathrm{Ca}$ and $\mathrm{Mg}$ in both experiments. Because $\mathrm{Ca}$ and $\mathrm{Mg}$ are

Table 5. Analysis of variance (ANOVA) values for block $(\mathrm{n}=8)$, experiment (spring and fall), sample time (ST) (pre-sample: before Plutella xylostella introduction, and post-sample: completion of experiment), and the experiment $\times$ ST interaction associated with the leachate variables. ${ }^{2}$

\begin{tabular}{|c|c|c|c|c|c|c|c|c|c|c|c|c|c|c|c|}
\hline \multirow[b]{2}{*}{ Main effects ${ }^{y}$} & \multicolumn{3}{|c|}{$\mathrm{N}(\mathrm{ppm})$} & \multicolumn{3}{|c|}{$\mathrm{P}(\mathrm{ppm})$} & \multicolumn{3}{|c|}{$\mathrm{K}(\mathrm{ppm})$} & \multicolumn{3}{|c|}{$\mathrm{pH}$} & \multicolumn{3}{|c|}{$\mathrm{EC}^{\mathrm{x}}$} \\
\hline & $\mathrm{F}$ & $\mathrm{df}$ & $P$ & $\mathrm{~F}$ & df & $P$ & $\mathrm{~F}$ & $\mathrm{df}$ & $P$ & $\mathrm{~F}$ & $\mathrm{df}$ & $P$ & $\mathrm{~F}$ & $\mathrm{df}$ & $P$ \\
\hline Block & 0.76 & 7 & 0.62 & 0.65 & 7 & 0.71 & 1.1 & 7 & 0.37 & 1.99 & 7 & 0.06 & 3.57 & 7 & $\overline{0.001}$ \\
\hline Experiment & 0.01 & 1 & 0.93 & 0.001 & 1 & 0.98 & 0.01 & 1 & 0.92 & 4.71 & 1 & 0.03 & 95.29 & 1 & $<0.001$ \\
\hline ST & 65.56 & 1 & $<0.001$ & 57.47 & 1 & $<0.001$ & 94.42 & 1 & $<0.001$ & 138.2 & 1 & $<0.001$ & 48.54 & 1 & $<0.001$ \\
\hline Experiment $\times \mathrm{ST}$ & 6.45 & 1 & 0.01 & 3.58 & 1 & 0.06 & 6.59 & 1 & 0.01 & 11.95 & 1 & $<0.001$ & 22.41 & 1 & $<0.001$ \\
\hline
\end{tabular}

zThere were 126 plants used with four containers per fertility treatment in each of eight blocks at two sampling times for the two experiments.

'Bolded values are significant at $P \leq 0.05$.

${ }^{\mathrm{x}}$ Reported in $\mathrm{mhos} / \mathrm{cm}$.

$\mathrm{N}=$ nitrogen; $\mathrm{P}=$ phosphorus; $\mathrm{K}=$ potassium; $\mathrm{EC}=$ electrical conductivity. 


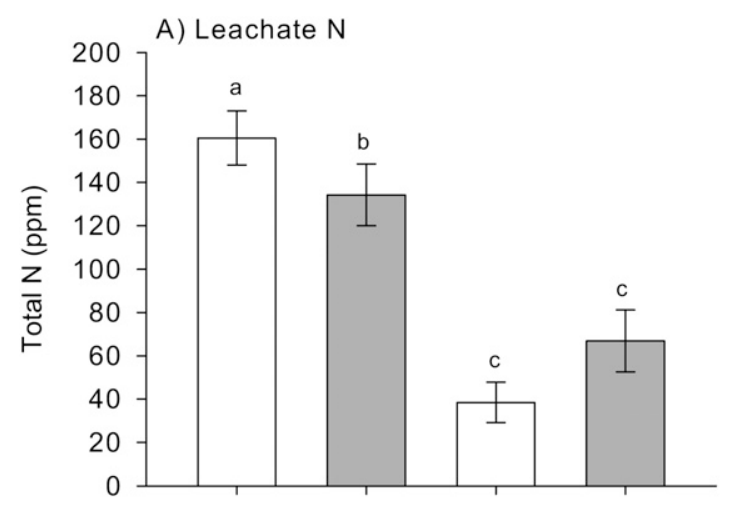

C) Leachate $\mathrm{pH}$

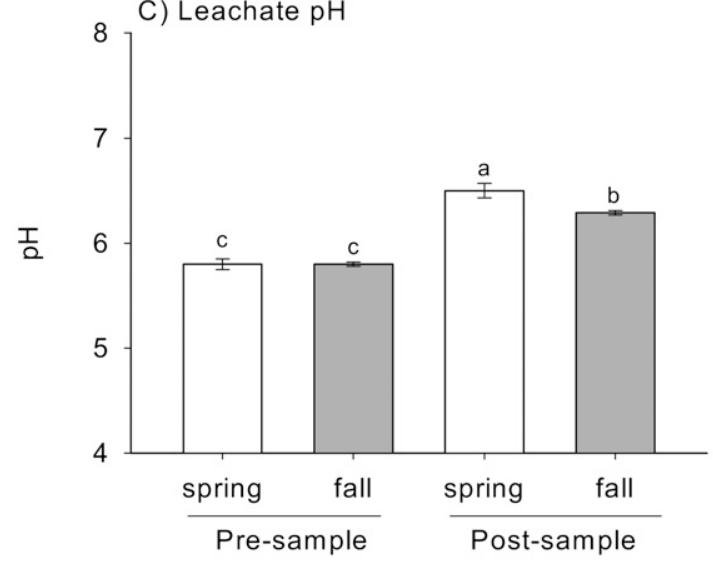

B) Leachate $\mathrm{K}$

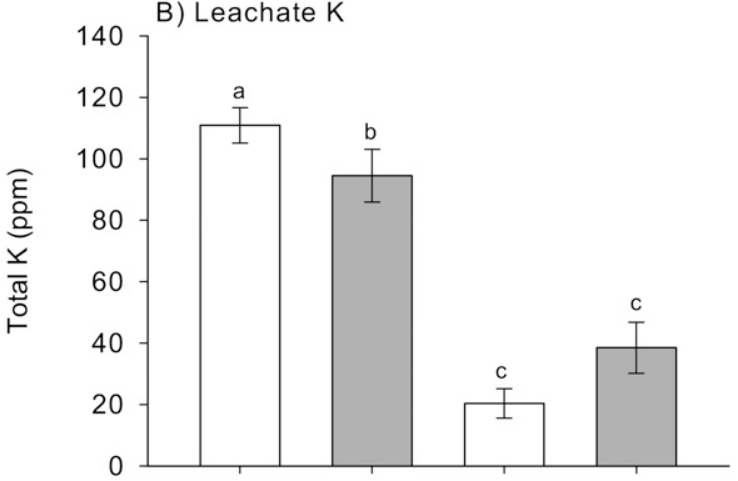

D) Leachate EC

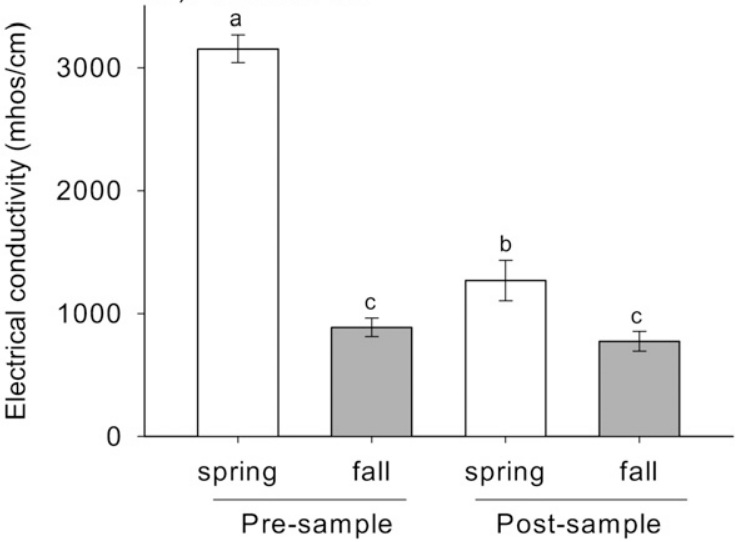

Fig. 3. Mean ( $\pm \mathrm{SE}$ ) leachate $(\mathbf{A})$ total nitrogen $(\mathrm{N}),(\mathbf{B})$ total potassium $(\mathrm{K}),(\mathbf{C}) \mathrm{pH}$, and (D) electrical conductivity (EC) from Brassica rapa containers before diamondback moth, Plutella xylostella, introduction (pre-sample) and at the end of the experiment (post-sample) for the spring and fall experiments. There were 126 containers used with four containers per fertility treatment in each of eight blocks at two sampling times for the two experiments. Vertical bars with a different letter are significantly different based on Fisher's protected least significant difference (LSD) test at $P \leq 0.05$.

associated with plant defenses related to stress, it may be expected that levels of both nutrients would increase in response to DBM herbivory (Kolupaev et al., 2008; RodriguezSerrano et al., 2009). Likewise, Sarfraz et al. (2009) found significantly higher percentages of $\mathrm{Ca}$ and $\mathrm{Mg}$ in the leaf tissues of Brassica napus that had been infested with DBM compared with uninfested plants. With respect to insect defense, Sarfraz et al. (2009) also found that plants with higher levels of $\mathrm{Ca}$ and $\mathrm{Mg}$ resulted in longer development times and shorter adult lifespans of DBM.

In both experiments, DBM had a significantly higher survival rate and developed faster on plants treated with the conventional fertilizer. Although neither larval consumption nor adult body weight were affected by the type of fertility treatment, our findings suggest that plant factors associated with the organic fertility treatment were less suitable for DBM compared with the conventional fertility treatment. However, there is no clear explanation for the observed differences in development and survival. The impact of different greenhouse conditions (light, temperature, and relative humidity) is not known on DBM fitness in this study but significantly varied between experiments. It is possible that the lower level of $\mathrm{P}$ in pac choi leaves in the organic fertility treatment adversely affected DBM. For example, $P$ availability during larval development may be an important factor influencing insect life history parameters (Visanuvimol and Bertram, 2011), and decreased dietary $\mathrm{P}$ has been shown to reduce the growth rate of Choristoneura occidentalis and Manduca sexta larvae (Clancy and King, 1993; Perkins et al., 2004). However, DBM development was not correlated with leaf $\mathrm{P}$ in the current study. Alternatively, treatment differences in other unmeasured plant components such as amino acid composition and concentration or changes in glucosinolate content may have affected the nutritional quality of pac choi for DBM. For example, Bejai et al. (2010) found specific glucosinolate levels (1-methoxyindol-3-ylmethylglucosinolate, 3 - benzoyloxypropylglucosinolate and 4-hydroxybenzylglucosinolate) were associated with increased DBM pupal weight and prolonged larval development in Arabidopsis thaliana. We did not assess specific glucosinolate levels in our study as a result of constraints of time and plant tissue required for analysis. Furthermore, changes in total glucosinolate content in Brassica plants have not been found to be associated with DBM larval performance (Arany et al., 2008; Ratzka et al., 2002).

As a result of the difficulties in managing DBM in crop production systems (Eigenbrode and Shelton, 1990), the current study contributes information that may be useful to producers. First, both fertility treatments appeared to provide comparable $\mathrm{N}$ sources for growth of pac choi. When implementing an organic fertility program, producers may choose fish-based fertilizers that deliver $\mathrm{N}$ to plants similar to conventional fertilizers, which is different from slower-release plantbased fertilizers and compost amendments. As such, future research, evaluating the use of multiple organic-based materials, is warranted. Second, it appears that the effect of the organic fertility treatment negatively impacted DBM development and survival. Although general predictions regarding pac choi susceptibility to DBM feeding under organic fertility programs compared with conventional fertility programs cannot be made at present, further studies may demonstrate that crop susceptibility changes may be associated with the type of fertilizer used. The possibility that the fish hydrolysate fertilizer induced pac choi defenses against DBM should be examined further by focusing on leaf P levels or other components affiliated with the hydrolysate formulation not measured in this study.

\section{Literature Cited}

Altieri, M.A., C. Nicholls, and M.A. Fritz. 2005. Manage insects on your farm: A guide to ecological strategies. Sustainable Agriculture Network Handbook Series Book 7. National Agricultural Laboratory, Beltsville, MD.

Altieri, M.A. and C.I. Nicholls. 2003. Soil fertility management and insect pests: Harmonizing 
soil and plant health in agroecosystems. Soil Tillage Res. 72:203-211.

Altimimi, M.E. 2010. Nitrate-nitrogen sufficiency ranges in leaf petiole sap of pac choi grown with organic and conventional fertilizers. Master's thesis, Kansas State University, Manhattan, KS.

Ansari, S.M., T. Ahmad, and H. Ali. 2010. Effect of Indian mustard on feeding, larval survival, and development of $P$. xylostella at constant temperatures. Entomol. Res. 40:182-188.

Arany, A.M., T.J. Jong, H.K. Kim, N.M. Dam, Y.H. Choi, R. Verpoorte, and E. Meijden. 2008. Glucosinolates and other metabolites in the leaves of Arabidopsis thaliana from natural populations and their effects on a generalist and a specialist herbivore. Chemoecology 18:65-71.

Aung, L.H. and G.J. Flick, Jr. 1980. The influence of fish solubles on growth and fruiting of tomato. HortScience 15:32-33.

Behmer, S.T. 2009. Insect herbivore nutrient regulation. Annu. Rev. Entomol. 54:165-187.

Bejai, R., U. Sarosh, B.A. Wittstock, B.A. Halkier, and B. Ekbom. 2010. The influence of metabolically engineered glucosinolates profiles in Arabidopsis thaliana on Plutella xylostella preference and performance. Chemoecology 20:1-9.

Bellotti, A.C., B.V. Arias, and O.L. Guzman. 1992. Biological control of the cassava hornworm Erinnyis ello (Lepidoptera: Sphingidae). Fla. Entomol. 754:506-515.

Brandt, K. and J.P. Molgaard. 2001. Organic agriculture: Does it enhance or reduce the nutritional value of plant foods? J. Sci. Food Agr. 81:924-931.

Bryant, J.P., F.S.I.I.I. Chapin, and D.R. Klein. 1983. Carbon nutrient balance of boreal plants in relation to vertebrate herbivory. Oikos 40:357-368.

Bryant, J.P., T.P. Clausen, P.B. Reichardt, M.C. McCarthy, and R.A. Werner. 1987. Effect of nitrogen fertilization upon the secondary chemistry and nutritional value of quaking aspen (Populus tremuloides Michx.). Oecologia 73:513-517.

Cavins, T.J., B.E. Whipker, and W.C. Fonteno. 2008. PourThru: A method for monitoring nutrition in the greenhouse. In: Michel, J.-C. (ed.). Proc. of the International Society of Growing Media. Acta Hortic. 779:289-297.

Chen, Y.-Z., C. Lin, C.-W. Wang, C.-C. Yeh, and S.-Y. Hwang. 2004. Response of two Pieris (Lepidoptera: Pieridae) species to fertilization of a host plant. Zool. Stud. 43:778-786.

Clancy, K.M. and R.M. King. 1993. Defining the western spruce budworm's nutritional niche with response surface methodology. Ecology 74:442-454.

Dallal, G.E. 2007. The little handbook of statistical practice. USDA Human Nutrition Research Center on Aging, Tufts University, Boston, MA. Apr. 2011. <http://www.jerrydallal.com/ LHSP/LHSP.HTM>.

Dudt, J.F. and D.J. Shure. 1994. The influence of light and nutrients on foliar phenolics and insect herbivory. Ecology 75:86-98.

Eigenbrode, S.D. and A.M. Shelton. 1990. Behavior of neonate diamondback moth larvae (Lepidoptera: Plutellidae) on glossy-leafed resistant Brassica oleracea L. Environ. Entomol. 19:1566-1571.

Emino, E.R. 1981. Effectiveness of fish soluble nutrients as fertilizers on container-grown plants. HortScience 16:338.

Fageria, N.K. 2005. Soil fertility and plant nutrition research under controlled conditions: Basic principles and methodology. J. Plant Nutr. 28:1975-1999.
Folgarait, P.J. and D.W. Davidson. 1995. Myrmecophytic cecropia: Antiherbivore defenses under different nutrient treatments. Oecologia 104:189-206.

Gardner, W.H. 1965. Water content, p. 82-127. In: Black, C.A., D.D. Evans, J.L. White, L.E. Ensminger, and F.E. Clark (eds.). Methods of soil analysis. Part 1. Physical and mineralogical properties, including statistics of measurement and sampling. American Society of Agronomy, Madison, WI.

Geisler, F.R. 1998. Effects of organic manures on a host crop-pest relationship. In: Allen, P. and D. Van Dusen (eds.). Global perspectives in agroecology and sustainable agricultural systems. Proc. of the VI International Scientific Conference of Organic Agriculture Movements. University of California, Santa Cruz, CA.

Hartz, T.K. and P.R. Johnstone. 2006. Nitrogen availability from high-nitrogen containing organic fertilizers. HortTechnology 69:39-42.

Hsu, Y., T. Shen, and S. Hwang. 2009. Soil fertility management and pest responses: A comparison of organic and synthetic fertilization. J. Econ. Entomol. 102:160-169.

Hummel, R.L., J.F. Walgenbach, G.D. Hoyt, and G.G. Kennedy. 2002. Effects of vegetable production system on epigeal arthropod populations. Agr. Ecosyst. Environ. 93:177-188.

Inbar, M., H. Doostdar, and R.T. Mayer. 2001. Suitability of stressed and vigorous plants to various insects. Oikos 94:228-235.

Johnson, W.A. 2011. Effects of light intensity and nitrogen source on pac choi (Brassica rapa L.), and interaction with the diamondback moth (Plutella xylostella L.). PhD diss., Kansas State University, Manhattan, KS.

Jones, C.G. and S.E. Hartley. 1999. A protein competition model of phenolic allocation. Oikos $86: 27-44$.

Jones, J.B., Jr. 1998. Plant nutrition manual. CRC Press, Boca Raton, FL.

Kolupaev, Y.Y., U.V. Karpets, and I.V. Kosakivska. 2008. The importance of reactive oxygen species in the induction of plant resistance to heat stress. Gen. Appl. Plant Physiol. 34:251-266.

Kristinsson, H.R. and B.A. Rasco. 2000. Fish protein hydrolysates: Production, biochemical, and functional properties. Crit. Rev. Food Sci. Nutr. 40:43-81.

Lamari, L. 2002. Assess: Image Analysis Software for plant disease quantification V1.0. American Phytopathological Society, St. Paul, MN.

Le Bot, J., C. Benard, C. Robin, F. Bourgaud, and S. Adamowicz. 2009. The trade-off between synthesis of primary and secondary compounds in young tomato leaves is altered by nitrate nutrition: Experimental evidence and model consistency. J. Expt. Bot. 60:4301-4314.

Letourneau, K.D. and A. van Bruggen. 2006. Crop protection in organic agriculture, p. 93-114. In: Kristiansen, P., A. Taji, and J. Reganold (eds.). Organic agriculture: A global perspective. CSIRO Publishing, Collingwood, Victoria, Australia.

Mengel, K. 1992. Agricultural productivity and environmental problems, p. 1-10. In: Mengel, K. and D.J. Pilbeam (eds.). Nitrogen metabolism in plants. Proc. of the phytochemical society of Europe. Clarendon Press, Oxford, New York, NY.

Muhamad, O., R. Tsukuda, Y. Oki, K. Fujisaki, and F. Nakasuji. 1994. Influences of wild crucifers on life history traits and flight ability of the diamondback moth, Plutella xylostella. Pop. Ecol. Res. 36:53-62.

Nicolle, C., A. Carnat, D. Fraisse, J. Lamaison, E. Rock, H. Michel, P. Amouroux, and C. Remesy. 2004. Characterization and variation of antioxidant micronutrients in lettuce (Lactuca sativa). J. Food Sci. Agr. 84:2061-2069.

Oelhaf, R.C. 1978. Organic farming: Economic and ecological comparisons with conventional methods. John Wiley, New York, NY.

Oh, M.-M. 2008. Plant adaptation and enhancement of phytochemicals in lettuce in response to environmental stresses. $\mathrm{PhD}$ diss., Kansas State University, Manhattan, KS

Oh, M.-M. and C.B. Rajashekar. 2009. Antioxidant content of edible sprouts: Effects of environmental shocks. J. Food Sci. Agr. 89:22212227.

Pennycooke, J.C., S. Cox, and C. Stushnoff. 2005. Relationship of cold acclimation, total phenolic content and antioxidant capacity with chilling tolerance in petunia (Petunia $\times$ hybrida). Environ. Exp. Bot. 53:225-232.

Penuelas, J. and M. Estiarte. 1997. Trends in plant carbon concentration and plant demand for nitrogen throughout this century. Oecologia 109:69-73.

Perkins, M.C., H.A. Woods, J.F. Harrison, and J.J. Elser. 2004. Dietary phosphorus affects the growths of larval Manduca sexta. Arch. Insect Biochem. Physiol. 55:153-168.

Phelan, P.L., J.F. Mason, and B.R. Stinner. 1995. Soil-fertility management and host preference by European corn borer, Ostrinia nubilalis (Hubner), on Zea mays L.: A comparison of organic and conventional chemical farming. Agr. Ecosyst. Environ. 56:1-8.

Pratissoli, D., J.-C. Zanuncio, R. Barros, and H. Nonato de Oliveira. 2002. Leaf consumption and duration of instars of the cassava defoliator Erinnyis ello (Lepidoptera, Sphingidae). Rev. Bras. Entomol. 46:251-254.

Ratzka, A., H. Vogel, D.J. Kliebenstein, T. MitchellOlds, and J. Kroymann. 2002. Disarming the mustard oil bomb. Proc. Natl. Acad. Sci. USA 99:11223-11228.

Raven, J.A. and F.A. Smith. 1976. Nitrogen assimilation and transport in vascular land plants in relation to intracellular $\mathrm{pH}$ regulation. New Phytol. 76:415-431.

Rodriguez-Serrano, M., M.C. Romero-Puertas, D.M. Pazmino, P.S. Testillano, M.C. Risueno, L.A. del Rio, and L.M. Sandalio. 2009. Cellular response of pea plants to cadmium toxicity: Cross talk between reactive oxygen species, nitric oxide, and calcium. Plant Physiol. 150: 229-243.

Sarfraz, R.M., L.M. Dosall, A.J. Blake, and B.A. Keddie. 2010. Leaf nutrient levels and the spatio-temporal distributions of Plutella $x y$ lostella and its larval parasitoids Diadegma insulare and Microplitis plutellae in canola. BioControl 55:229-244.

Sarfraz, R.M., L.M. Dosdall, and A.B. Keddie. 2009. Bottom-up effects of host plant nutritional quality on Plutella xylostella (Lepidoptera: Plutellidae) and top-down effects of herbivore attack on plant compensatory ability. Eur. J. Entomol. 106:583-594.

Sarfraz, R.M., L.M. Dosall, B.A. Keddie, and J.H. Myers. 2011. Larval survival, host plant preferences and developmental responses of the diamondback moth Plutella xylostella (Lepidoptera: Plutellidae) on wild Brassica species. Entomol. Sci. 14:20-30.

SAS Institute. 2002. SAS: Stat user's guide. Version 9.1. SAS Institute, Cary, NC.

Scriber, J.M. and F. Slansky, Jr. 1981. The nutritional ecology of immature insects. Annu. Rev. Entomol. 26:183-211.

Shirai, Y. 1993. Factors influencing flight ability of male adults of the diamondback moth, Plutella xylostella, with special reference to temperature 
conditions during the larval stage. Appl. Entomol. Zool. (Jpn.) 28:291-301.

Staley, J.T., A. Stewart-Jones, T.W. Pope, D.J. Wright, S.R. Leather, P. Hadley, J.T. Rossiter, H.F. van Emden, and G.M. Poppy. 2010. Varying responses of insect herbivores to altered plant chemistry under organic and conventional treatments. Proc. Roy. Soc. Biol. Sci. 277: 779-786.
Talekar, N.S. and M.-Y. Lin. 1998. Biology of diamondback moth, p. 3-5. In: Diamondback moth training manual. Publication No. 98-472. Asian Vegetable Research and Development Center Shanhua, Tainan 741, Taiwan.

Visanuvimol, L. and S.M. Bertram. 2011. How dietary phosphorus availability during development influences condition and life history traits of the cricket, Acheta domesticus. J. Insect Sci. 11:63.
You, M.-S. and G. Yang. 2001. Physiological stress reaction of Chinese cabbage, Brassica chinensis, infested by diamondback moth, Plutella xylostella. Entomol. Sci. 8:131-140.

Zhao, X., J.R. Nechols, K.A. Williams, W. Wang, and E.E. Carey. 2009. Comparison of phenolic acids in organically and conventionally grown pac choi (Brassica rapa L. Chinensis group). J. Sci. Food Agr. 89:940-946. 